\title{
Salt tolerance of potato genetically engineered with the Atriplex canescens BADH gene
}

\author{
A. ALI ${ }^{1,2,3 *}$, Q. ALI ${ }^{3,4}$, M.S. IQBAL ${ }^{3}$, I.A. NASIR ${ }^{3}$, and X. WANG ${ }^{2 *}$ \\ Four Brothers Group Pakistan,77-D/1, 1 ${ }^{\text {st }}$ Floor Lahore Centre, Main Boulevard Gulberg, Lahore, \\ Punjab 54000, Pakistan ${ }^{1}$ \\ Department of Plant Pathology, China Agricultural University, Beijing 100093, P.R. China ${ }^{2}$ \\ Centre of Excellence in Molecular Biology, University of Punjab, Lahore, Punjab 53700, Pakistan ${ }^{3}$ \\ Institute of Molecular Biology and Biotechnology, University of Lahore, Lahore, Punjab 54000, Pakistan ${ }^{4}$
}

\begin{abstract}
Potato (Solanum tuberosum L.) is among the top staple foods in the world, and salinity adversely affects its yield and quality. To improve salt tolerance in potato, the present study is focused on the Agrobacterium-mediated transformation of potato by the Atriplex canescens betaine aldehyde dehydrogenase (BADH) gene driven by single, double, and triple CaMV $35 \mathrm{~S}$ promoters. The study led first to the detection of seven lines containing the $B A D H$ gene followed by the identification of T-DNA insertions via DNA hybridization and enzyme-linked immunosorbent assays. The salt tolerance was found to be promoter dependent, as the lines with triple promoters showed a higher resistance than those tranformed with single and double promoters. The transgenic lines showed lower content of $\mathrm{H}_{2} \mathrm{O}_{2}$ and malondialdehyde and a lower relative electrical conductivity than wild-type plants. Furthermore, these lines also showed higher proline and chlorophyll content. In silico analysis confirmed that the $A$. canescens BADH protein had a remarkable tendency to interact with sodium ions and water molecules like other BADH proteins. Taken together, the overexpression of $B A D H$ under triple CaMV 35S promoters enhanced salt tolerance of potato.
\end{abstract}

Additional key words: Atriplex canescens, CaMV 35S promoter, chlorophyll, malondialdehyde, proline, Solanum tuberosum.

\section{Introduction}

Potato is ranked high among the leading staple foods in the world. Cultivated potatoes are susceptible to various biotic and abiotic stresses (Axel et al. 2012). Among abiotic stresses, salt stress is the most lethal one and causes enormous economic loss worldwide (Sudhersan et al. 2012, Levy and Tai 2013). The incorporation of resistant genes in the host plant and organized breeding are the most effective approaches to developing new lines with increased salt tolerance and higher yield (Krivosheeva et al. 2014). To protect and maintain cellular metabolism and cellular components, plants use different mechanisms (Jbir-Koubaa et al. 2014). Osmoprotectant accumulation is the most common mechanism against salinity stress in plants (Si et al. 2012).

Glycinebetaine is a bipolar quaternary ammonium compound. It can help to maintain osmotic balance with the environment and to stabilize complex quaternary structure of proteins; thus it protects cells against salt stress (Giri 2011). In plants, glycinebetaine is synthesized in two steps: conversion of choline to betaine aldehyde and then betaine aldehyde to glycine betaine (Mitsuya et al. 2011, Rajaeian et al. 2017). Betaine aldehyde dehydrogenase $(\mathrm{BADH})$ is the enzyme that catalyzes the second step in the synthesis of glycine betaine. The $B A D H$ gene has been cloned from many species, such as Spinacia oleracea (Luo et al. 2012), Atriplex hortensis (Xiao et al. 2013), Sorghum bicolor (Wood et al. 2013), Avicennia marina (DíazSánchez et al. 2012), and Beta vulgaris (Luo et al., 2012). BADH is a homodimer of nuclear-encoded subunits and has a molecular mass of $60 \mathrm{kDa}$ (Rathinasabapathi et al. 1997). Betaine aldehyde dehydrogenase (BADH) belongs to the aldehyde dehydrogenase super family (Yu et al. 2017).

There is a wide diversity in the structure of enzymes with BADH activity; however, in the majority of plants $\mathrm{BADH}$ is a dimeric protein (Weretilnyk and Hanson 1989).

Submitted 17 December 2018, last revision 9 June 2019, accepted 11 June 2019.

Abbreviations: BADH - betaine aldehyde dehydrogenase; MDA - malondialdehyde; MS - Murashige and Skoog; REC - relative electrical conductivity; SIM - sulfide indole motility.

Acknowledgements: The authors highly acknowledge the Higher Education Commission of Pakistan for providing scholarship and the National Natural Science Foundation of China (31601600) for financial support to this research.

*Corresponding authors; wxd_210@126.com, saim1692@gmail.com 
The conversion of betaine aldehyde to glycine betaine catalyzed by $\mathrm{BADH}$ is dependent on the oxidation of the cofactors $\mathrm{NAD}^{+}$or $\mathrm{NADP}^{+}$(Fujiwara et al. 2008) which predominantly accumulate in the leaves and stems of a diverse range of dicotyledons and some monocotyledons (Ishitani et al. 1993). Plant abiotic stress resistance is often mediated by increasing BADH activity (Nakamura et al. 2015). The presence of different $B A D H$ genes has been reported in plants and they show minor sequence differences. However, some plant species (tomato, Arabidopsis thaliana, tobacco, and potato) accumulate low amounts of glycinebetaine. We used $B A D H$ gene from Atriplesx canescens because it has been well documented that this species provides better salt tolerance compared with many other species, and this $B A D H$ also has promoterdependent activity (Jia et al. 2002).

The current research was designed with the following five objectives: 1) to induce salt resistance through incorporating the $B A D H$ gene into potato lines; 2) to investigate the glycinebetaine biosynthesis pathway; $3)$ to assess promoter efficiency in enhancing salt tolerance; 4) to check the frequency of the $B A D H$ gene, followed by T-DNA insertion identification, DNA hybridization, and enzyme-linked immunosorbent assays; and 5) to monitor the $B A D H$-induced biosynthesis of glycinebetaine in transgenic plants using single, double, and triple $C A M V 35 S$ promoters and correlate promoter frequency with salt tolerance.

\section{Materials and methods}

Plants: Atriplex canescens Nutt. (salt bush) plants were collected from district Muzaffargarh, South Punjab, Pakistan. The potato (Solanum tuberosum L. cv. AGBRed) tubers were collected from district Lahore, Central Punjab, Pakistan. For experiments we used the wild-type lines (WT1, WT2, WT5, WT7, WT8, WT9, and WT10) and transgenic plants with inserted $B A D H$ gene under CAMV 35S promoter (lines T1, T5a, T5b, T5c, T7a, T7b, T7c, T9, and T10) (Figs. 1 and 2 Suppl.).

Extraction of DNA, cDNA synthesis, and PCR: Genomic DNA from $A$. canescens was isolated using a DNA isolation kit (Fermentas, Burlington, Canada), and cDNA was synthesized using a Super-Script III kit (Invitrogen, Carlsbad, USA). PCR was performed using $1 \mathrm{~mm}^{3}$ of cDNA (100 ng) in a final volume of $30 \mathrm{~mm}^{3}$ along with 10 pmol of each primer, $0.25 \mathrm{mM} \mathrm{dNTP}$, and $1 \mathrm{~mm}^{3}$ of Taq polymerase with its respective buffer. The PCR was performed with up to 40 cycles according to the following program: denaturation at $95{ }^{\circ} \mathrm{C}$ for $1 \mathrm{~min}$ and again at $94{ }^{\circ} \mathrm{C}$ for $2 \mathrm{~min}$, annealing at $45^{\circ} \mathrm{C}$ for $1 \mathrm{~min}$, extension at $72^{\circ} \mathrm{C}$ for $1.5 \mathrm{~min}$ and a final extension at $72^{\circ} \mathrm{C}$ for $10 \mathrm{~min}$.

Gene construct and genetic transformation of potato tubers: Total cDNA from Atriplex was used for fulllength amplification of the $B A D H$ gene $(1.5 \mathrm{~kb})$ according to the procedure of Zhang and Shi (2013). The gene was positioned successively under the control of triple, double, and single $C A M V 35 S$ promoters in the $p C A M B I A 1301$ plant expression vector under Hind111, BamH1, and Kpn 1 restriction sites, respectively, and confirmed via restriction digestion with the aforementioned restriction enzymes (Fig. 1). The constructs were transformed into Solanum tuberosum via the Agrobacterium-mediated transformation method. The surface sterilization of potato tubers was performed using $0.2 \%(\mathrm{~m} / \mathrm{v}) \mathrm{HgCl}_{2}$ for $20 \mathrm{~s}$ and $75 \%(\mathrm{v} / \mathrm{v})$ ethanol for $5 \mathrm{~min}$, followed by rinsing with distilled water ten times. After rinsing, the tubers were kept on filter paper overnight to dry. Murashige and Skoog (1962; MS) medium was used for the germination of sterilized seeds under a 18-h photoperiod and a temperature of $25^{\circ} \mathrm{C}$. After 2 weeks, nodes were again precultured in the dark and $25^{\circ} \mathrm{C}$ on MS and callus induction medium ( $\left.\mathrm{pH} 5.8\right)$ for $2 \mathrm{~d}$. The medium was supplemented with $3 \%(\mathrm{~m} / \mathrm{v})$ sucrose, $2 \mathrm{~g} \mathrm{dm}^{-3}$ casein acid, $4.0 \mathrm{mg} \mathrm{dm}^{-3}$ hydrolysate, and $1.0 \mathrm{mg} \mathrm{dm}^{-3}$ 6-furfuryl-aminopurine (kinetin) and 2,4-dichlorophenoxyacetic acid (2,4-D). Agrobacterium tumefaciens was grown in YEP medium $(\mathrm{pH}$ 7.2; $5 \mathrm{~g} \mathrm{dm}^{-3} \mathrm{NaCl}, 10 \mathrm{~g} \mathrm{dm}^{-3}$ yeast extract, $10 \mathrm{~g} \mathrm{dm}^{-3}$ peptone, $2 \mathrm{mM} \mathrm{MgCl}_{2}$ ) supplemented with $50 \mathrm{mg} \mathrm{dm}^{-3}$ rifampicin and $50 \mathrm{mg} \mathrm{dm}^{-3}$ kanamycin. The murky medium was subjected to continuous agitation at $25^{\circ} \mathrm{C}$ until the Agrobacterium attained an absorbance $\left(\mathrm{A}_{600}\right)$ of 0.8 . The Agrobacterium suspension was collected by centrifugation (1000 $\mathrm{g}$ for $10 \mathrm{~min}$ ) and was re-suspended in a Schenk and Hildebrand liquid medium [0.1 MS medium supplemented with $1 \%(\mathrm{~m} / \mathrm{v})$ glucose, $4 \%(\mathrm{~m} / \mathrm{v})$ sucrose, $0.1 \mathrm{mg} \mathrm{dm}^{-3}$ 6-benzylaminopurine, $5 \mathrm{mg} \mathrm{cm}^{-3} 2,4 \mathrm{D}$ ] to absorbance at $600 \mathrm{~nm}$ of 0.8 was achieved. Explants remained in the Agrobacterium suspension for $30 \mathrm{~min}$ in the dark. Afterward, the explants were blotted on filter paper and then cultivated in callus induction medium that was supplemented with both $50 \mathrm{mg} \mathrm{cm}^{-3}$ kanamycin and $100 \mathrm{mg} \mathrm{cm}^{-3}$ cefotaxime for 2 weeks. After two weeks, the resistant explants were transported to drug-free MS medium.

Identification of transgenic plants via PCR and reverse transcription PCR: Transgenic and wild-type potato plants were used for DNA isolation; total genomic DNA

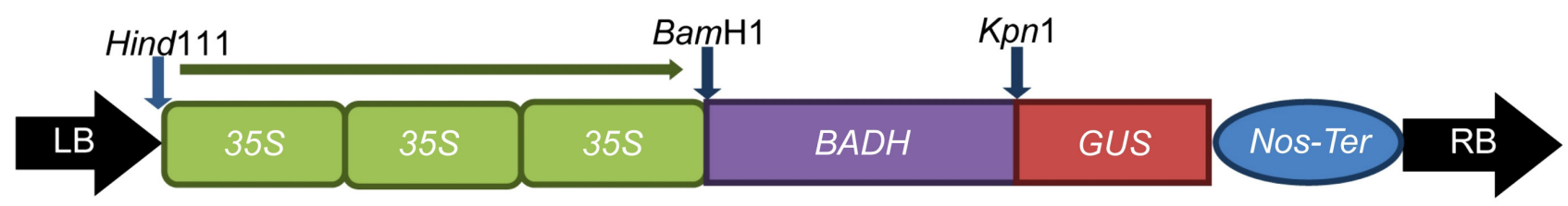

Fig. 1. Construction of plant expression vector carrying the betaine aldehyde dehydrogenase $(B A D H)$ gene. LB - left border, RB -right border, $35 S$ - cauliflower mosaic virus $35 S$ promoter, NoS - nopaline synthase terminator. 
was isolated using a K0513 DNA isolation kit (Fermentas, Waltham, MA, USA). Integration was confirmed using the following full-length primers: $B A D H$-forward, ATGGCGTTTCCTATTCCTGTTC, and $B A D H$-reverse, TTAAGGAGACTTGTACCAGCC. A $1.5-\mathrm{kb}$ product was revealed and separated on $0.8 \%(\mathrm{~m} / \mathrm{v})$ agarose gel. Ribonucleic acid was extracted using a GeneJET plant RNA purification kit K0801 (Ambion, Vilnius, Lithuania), and complementary DNA was synthesized using a Super-Script III kit (Invitrogen, Waltham, MA, USA). First-strand cDNA was synthesized from $1 \mu \mathrm{g}$ of total RNA using reverse transcriptase. Of that, $2 \mathrm{~mm}^{3}$ was used as a template in a total reaction volume of $25 \mathrm{~mm}^{3}$ along with a SYBR Green PCR Master Mix reaction mixture (Applied Biosystems, Waltham, MA, USA). The expression of BADH transcripts was assessed using primers (BADH-SF, GTTTAGCTGGTGCCGTGTTT, $B A D H$-SR, ATACCCCATTCCCCAAGTTC) under the following conditions: denaturation at $94{ }^{\circ} \mathrm{C}$ for $3 \mathrm{~min}$, $94{ }^{\circ} \mathrm{C}$ for $30 \mathrm{~s}$, annealing at $55^{\circ} \mathrm{C}$ for $45 \mathrm{~s}$, and $72{ }^{\circ} \mathrm{C}$ for $1 \mathrm{~min}$. This was followed by a final cycle at $72{ }^{\circ} \mathrm{C}$ for $10 \mathrm{~min}$ to allow the completion of polymerization. Actin was used as an internal control using primers (Actin-F: 5'-ATGTTCCCGGGTATTGCTGACAGA-3' and Actin-R: 5'-CTGCCTTTGCAATCCACATCTGCT-3').

Hybridixation of DNA: The presence of the $B A D H$ gene in the potato genome was confirmed through DNA hybridization. Gene-specific probes were used for binding and were detected using their proper substrates. By hybridization of DNA on nitrocellulose membrane (Fermentas Biotin DecaLable ${ }^{\mathrm{TM}}$ DNA labeling kit), biotinlabeled $B A D H$ probe was estimated. Genomic DNA was digested with BamH1 and $K p n 1$ restriction enzymes and then transformed on to a Hybond- $N^{+}$nylon membrane after depurination and neutralization. To fix DNA, the membrane was exposed to UV radiation for 2 - $3 \mathrm{~min}$. Diluted $20 \mathrm{~mm}^{3}$ of streptavidin-alkaline phosphatase conjugate was applied to the membrane for $30 \mathrm{~min}$ after removing blocking solution. The membrane was washed twice with $1 \times$ blocking/washing buffer. After removal of washing buffer, the membrane was treated with detection buffer for half an hour. Enzymatic reaction was performed overnight by applying freshly prepared $1 \times 5$-bromo-4chloro-3-indolyl phosphate (BCIP) / nitro blue tetrazolium (NBT) in the dark.

Relative electrical conductivity assay and $B A D H$ activity of transgenes: After multiplication and rooting on MS medium with $\mathrm{NaCl}$ and a sulfide indole motility (SIM) medium (Jia et al. 2002), the transgenic potato plants were transplanted into pots and watered with MS solution containing $\mathrm{NaCl}$ at $0 \mathrm{mM}$ and $180 \mathrm{mM}$ MS medium. The SIM medium was designed for the detection of sulfide production, indole formation, and motility of Agrobacterium. The medium contained ferrous ammonium sulfate and sodium thiosulfate, which together serve as an indicator for the production of hydrogen sulfide $\left(\mathrm{H}_{2} \mathrm{~S}\right)$. The hydrogen sulfide production was detected when ferrous sulfide, a black precipitate, was produced due to the result of ferrous ammonium sulfate reacting with $\mathrm{H}_{2} \mathrm{~S}$. Casein peptone, another component of the SIM medium, is rich in tryptophan. The organism that possesses the enzyme tryptophanase degrades tryptophan in to indole. Indole is usually detected upon the addition of Kovacs reagent (Hemraj et al. 2013) to the incubation medium. Indole combines with $p$-dimethylaminobenzaldehyde and produces a red band at the top of the medium. A negative indole test produces no color change upon the addition of Kovacs Reagent. The small amount of agar added to the medium provides a semi-solid structure allowing for the detection of bacterial motility. Motile organisms extend from the stab line and produce turbidity or cloudiness throughout the medium. Non-motile organisms grow only along the stab line and leave the surrounding medium clear. The potato plants were watered with MS nutritional solution until they reached the 4-to-5 leaf stage. The third leaf from the top was used for relative electrical conductivity (REC) and $B A D H$ activity assays. Following the procedure of Guo et al. (1997), $B A D H$ activity was measured. Consuming $1 \mathrm{nM}$ NAD per minute in the reaction volume is defined as 1 unit of $B A D H$ activity. Each measurement was the average of three replicates. A Thermo ScientificOrion StarA112 (Thermo Electron LED, Illkirch Cedex, France) conductivity benchtop meter was used for REC testing. The transgenic lines and controls were stressed in $0,90,180$ or $270 \mathrm{mM} \mathrm{NaCl}$ solution for $24 \mathrm{~h}$. Immediately after stress treatments, the content of chlorophyll and malondialdehyde (MDA) was measured according to the procedure of Zhang and Shi (2013).

Proline content assay: Proline content was measured according to the procedure suggested by Bates et al. (1973). After homogenizing, $3 \%(\mathrm{~m} / \mathrm{v})$ sulfosalicylic acid $\left(3 \mathrm{~cm}^{3}\right)$ was used for digesting $\sim 150 \mathrm{mg}$ of leaves at $100{ }^{\circ} \mathrm{C}$ for $25 \mathrm{~min}$. The mixture was then centrifuged at $3000 \mathrm{~g}$ for $5 \mathrm{~min}$ and $2 \mathrm{~mm}^{3}$ of glacial acetic acid and $3 \mathrm{~cm}^{3}$ of ninhydrin were added to the $2 \mathrm{~cm}^{3}$ of supernatant. Samples were extracted with $5 \mathrm{~cm}^{3}$ of toluene after boiling for $40 \mathrm{~min}$. Proline content was calculated from a standard curve after determining the absorbance at $520 \mathrm{~nm}$.

Determination of glycine betaine: Glycine betaine content was measured according to Xing and Rajashekar (2001). Liquid nitrogen-freeze-dried samples of potato tubers were ground to a powder and incubated in redistilled water at $4{ }^{\circ} \mathrm{C}$ for $24 \mathrm{~h}$. Potato leaves were frozen in liquid nitrogen and thawed for expressing sap using a glass injector. The extracts of leaf samples and potato powders were centrifuged at $12500 \mathrm{~g}$ and $4{ }^{\circ} \mathrm{C}$ for $12 \mathrm{~min}$, and the supernatant was dried under a stream of nitrogen. The dried fractions were dissolved with $\mathrm{D}_{2} \mathrm{O}$, in which $1 \mathrm{mM}$ sodium dodecyl sulfate (SDS) acted as the internal reference for quantification, and ${ }^{1} \mathrm{H}$ spectra were determined using a Bruker AM500 NMR spectrometer (Beijing, China).

Protein analysis: The BADH protein content was detected by an enzyme linked immunosorbent assay ELISA which is an accurate, sensitive, and a rapid detection method for proteins. It is especially an effective method when large 
numbers of plant samples have to be assayed, and when results for protein test are needed rapidly even when the suitable indicator like plants and/or greenhouse facilities are even not available. For the detection of our BADH proteins ELISA was used as described by Wood et al. (2013).

In silico analysis: The ExPASy translate tool (Gasteiger et al. 2003) was used to determine the amino acid sequence of the $B A D H$ gene. This sequence was further used to predict the 3-D model for the BADH protein using MODELLER (Pieper et al. 2006) and viewed with Chimera (Hou and Bartels 2014). The predicted structure was verified using various analyses, e.g., ERRAT (http://servicesn.mbi.ucla. edu/ERRAT/), PROVE (http://servicesn.mbi.ucla.edu/ PROVE/), WHATCHECK (https://servicesn.mbi.ucla.edu/ WHATCHECK/), VERIFY3D (http://servicesn.mbi.ucla. edu/Verify3D/), and Ramachandran plots (http://mordred. bioc.cam.ac.uk/ rapper/rampage.php), and the 2-D structure annotation was calculated using the protein data bank $(P D B)$ database (http://www.ebi.ac.uk/thornton-srv/ databases/cgi-bin/pdbsum/GetPage.pl?pdbcode=index. html). The subcellular localization of the BADH protein was carried out in silico using multiple online protein localization prediction programs to eliminate the possibility of any false positive predictions. The tools used for this analysis included Prot Comp v. 9.0 (http://linux1. softberry.com/berry.phtml), MultiLoc2 (Zhang et al. 2014), CELLO v. 2.5 (Yu et al. 2006), and Euk-mPLoc 2.0 (Chou and Shen 2007). Additionally, the theoretical pI and $\mathrm{Mr}$ values were computed using the Expassy Compute $\mathrm{pI} / \mathrm{Mw}$ tool (web.expasy.org/compute_pi/). The 3D-BLAST was performed using the BioXGEM $3 D$-Blast protein structure search, available at http://3d-blast.life.nctu. edu.tw/, to identify the most functionally related protein. NCBI Genome Workbench v 2.9.0 was used to build alignment with Muscle of different $B A D H$ sequences of various species. These sequences were retrieved from $N C B I$ protein database using domain enhanced lookup time accelerated $B L A S T$. A neighbor-joining tree was built using the Poisson algorithm.

\section{Results}

After the amplification of Atriplex cDNA, $B A D H$ was ligated into the pCAMBIA1301 plant expression vector under single, double, and triple CaMV 35S promoters, and their ligation was confirmed through restriction digestion with Hind111, BamH1, and Kpn1 restriction enzymes, as shown in Fig. $2 B$. The construct was transformed in potato, and the putative transgenic shoots were sorted out using PCR with the gene-specific primers mentioned above. To test the expression of the $B A D H$ gene in transgenic potato (Figs 1 and 2 Suppl.), reverse transcription PCR was performed with T2 transgenic and wild-type plants (Fig. 6). Different $B A D H$ expressions were observed in T2 $B A D H$ transgenic lines with single, double, and triple CaMV $35 \mathrm{~S}$ promoters. Two lines (5 and 7) were positive for three constructs and were tested under all the three promoter constructs. Potential transgenic shoots were surface-sterilized to eliminate false positives arising from consistent Agrobacterium and transferred to a cefotaxime sodium-free SIM medium. No Agrobacterium appeared after 10 - $12 \mathrm{~d}$. PCR analysis detected a $1.5-\mathrm{kb}$ band in all 10 shoots obtained from the $\mathrm{SRM}$ medium $(\mathrm{NaCl}$ rich $\mathrm{MS}$ medium), while the wild type, which was used as control, did not show this band (Fig. 5A). The incorporation of the $B A D H$ gene in transgenic potato plants was confirmed through DNA hybridization. After binding, the probes were detected using proper substrates. Genomic DNA was digested using BamH1 and Kpn 1 restriction enzymes. Binding with gene-specific probes and the detection of a $1.5-\mathrm{kb}$ gene together confirmed the successful integration of the $B A D H$ gene in transgenic potato plants, as shown in Fig $5 B$.

An ELISA was used to evaluate BADH protein content in transgenic potato plants (Wood et al. 2013). Lines 5 and 7 were also subjected to ELISA with three different construct-isolated proteins. Total crude protein was isolated from other transgenic potato lines. The colour development and detection of the $B A D H$ protein, after applying gene-specific antibodies from Sigma Life
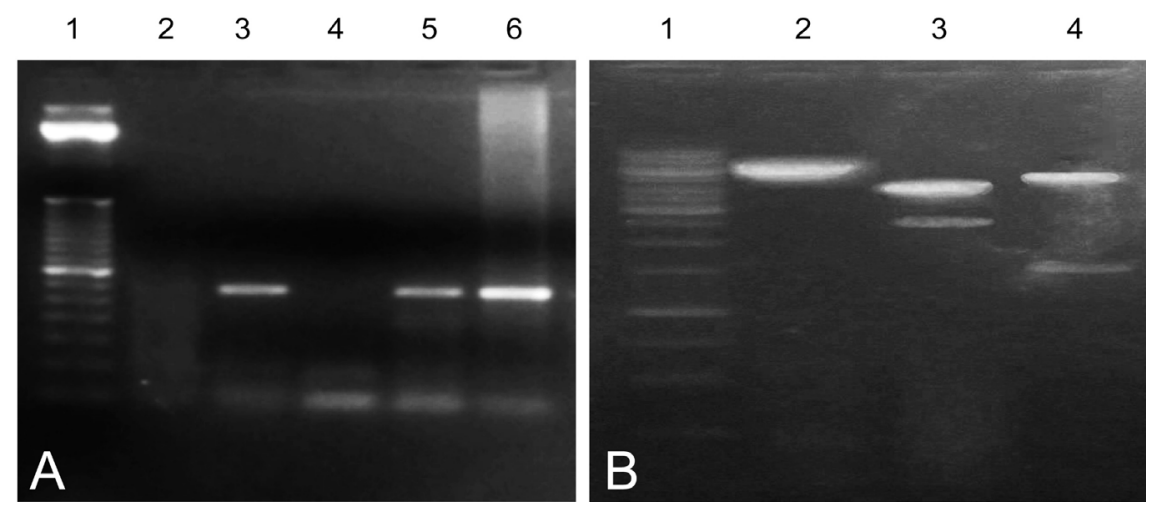

Fig. 2. A - Amplification by PCR of the betaine aldehyde dehydrogenase (BADH) from genomic cDNA of Atriplex. Lane 1-1-kb molecular mass marker, lane 2 - wild-type plants (without DNA), lanes 3-6 - BADH-positive samples. $B$ - Construct confirmation via restriction digestions. 1 - 1-kb ladder, 2 - complete cassette (pCAMBIA1301 + Triple CaMV 35S promoter + betaine aldehyde dehydrogenase), 3 - cassette digested with Hind111 and Kpn1 restriction enzymes contained in the pCAMBIA1301 vector (above) and triple promoter + the BADH (below), 4 - cassette digested with Bam $\mathrm{H} 1$ and $K p n 1$ containing only BADH. 

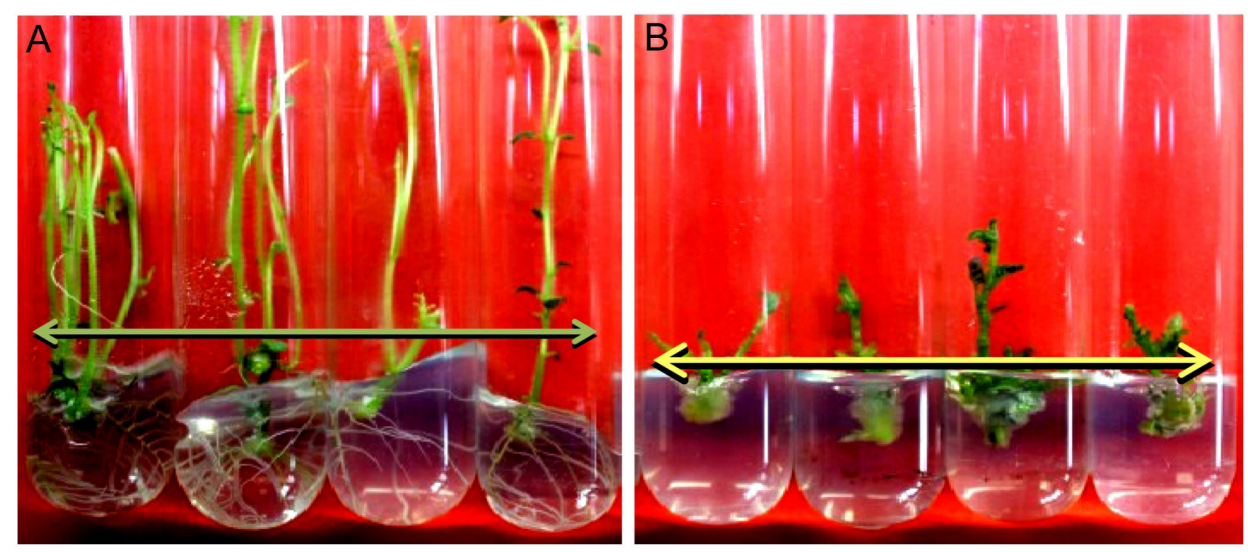

Fig. 3. Salt tolerance of potato transgenic lines. $A$ - transgenic lines rooted normally in Murashige and Skoog medium containing $90 \mathrm{mM}$ $\mathrm{NaCl} ; B$ - wild-type plants, which could form only a swelling such as a callus mass.

Science (Saint Louis, MO, USA), were performed using a 5-bromo-4-chloro-3-indolyl phosphate (BCIP) / nitro blue tetrazolium (NBT) substrate. The content of $B A D H$ protein was from 0.255 to $0.742 \mu \mathrm{g} \mathrm{g}^{-1}$ (f.m.) (Fig. 3 Suppl.).

To test whether $\mathrm{H}_{2} \mathrm{O}_{2}$ accumulation was affected by increased activity of $B A D H$, the $\mathrm{H}_{2} \mathrm{O}_{2}$ content was measured in both $B A D H$ transgenic lines and wild type plants. After salt stress, $\mathrm{H}_{2} \mathrm{O}_{2}$ content increased by 3.6 to 4 -fold in control plants and by 1.7 to 2 -fold in $B A D H$ transgenic lines. Lines 5 and 7 had lower $B A D H$ activity under the triple CaMV 35S promoter than under double and single promoter (Fig. 5 Suppl.). Higher chlorophyll content was observed in $B A D H$ transgenic lines compared to that in wild type plants (Fig. 5 Suppl. and Table 7 Suppl.).

The proline content increased with increasing $\mathrm{NaCl}$ stress in both $B A D H$ transgenic and wild type plants compared to untreated plants (Fig. 6 Suppl.). The accumulation of proline was higher in transgenic plants compared to that in wild type plants. Malondialdehyde content also increased with increasing salt stress. The MDA content was higher in $B A D H$ transgenic plants,

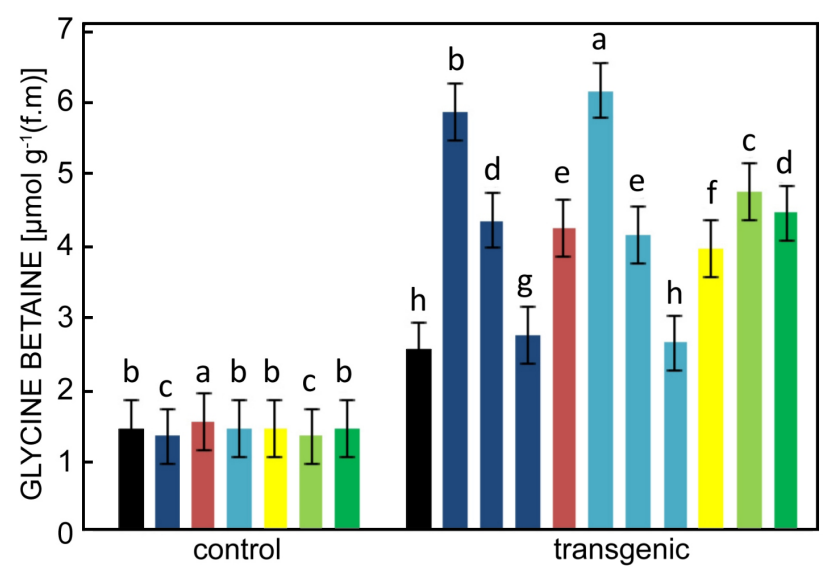

Fig. 4. Comparison of glycine betaine content in control (wildtype) plants and betaine aldehyde dehydrogenase (BADH) transgenic potato plants. Means \pm SEs of three experiments; different lowercase letters indicate significant differences (the Tukey's test, $P<0.05$ ). especially in lines 5 and 7, than in other transgenic lines and wild type plants (see Fig. 6 Suppl. and Table 7 Suppl.), respectively.

The T3 generation of the elite transgenic potato inbred line AGB-Red was used for the measurement of glycine betaine content in potato tubers and leaves by proton nuclear magnetic resonance $\left({ }^{1} \mathrm{H}-\mathrm{NMR}\right)$ spectroscopy. Glycinebetaine content in transgenic lines with $B A D H$ gene under a single promoter was 2 to 2.5 -fold higher compared with that of the wild type and 3 to 3.5 -fold higher under the double promoter, and 4 to 4.5 -fold higher under the triple promoter.

The 3-D structure of the $B A D H$ protein was predicted and validated using multiple $P D B$ validation tools (Fig. 7 Suppl.). ERRAT analysis predicted an overall quality factor of 81.504 . VERIFY3D tool results showed that $83.83 \%$ of the residues had an average 3D-1D score $\geq 0.2$. The Ramachandran plot showed that, of the 501 residues, almost $100 \%$ of phi and psi bond angles of the residues were in the favourable region, whereas those of only 1 residue were in the unfavourable region (Fig. 7 Suppl.). The 2-D structure annotation for helices, sheets, turns, and loops was determined using the $P D B$ sum generation tool (Fig. 8 Suppl.). Furthermore, BADH was found to be a multilocated protein as predicted by various computational tools that use different strategies for predicting protein localization. The BADH protein was found to be present mainly in the cytoplasm and to a lesser extent in peroxisomes and mitochondria. The theoretical $\mathrm{pI}$ and $\mathrm{Mr}$ values were 5.03 and $123614.45 \mathrm{Da}$. A protein $3 D$-Blast structure similarity search found that our queried protein was $83.0 \%$ identical to the crystal structure of aminoaldehyde dehydrogenase 2 from Pisum sativum (psamadh2) and $67.3 \%$ identical to the crystal structure of aminoaldehyde dehydrogenase 1 from Pisum sativum (psamadh1). Finally, we analyzed the phylogenetic lineage of the BADH protein by building phylogenetic tree. A total of 72 sequences, having an identity of more than $70 \%$, were retrieved from NCBI. These sequences included flowering plants and comprised both eudicots and monocots (Fig. 9 Suppl.).

Based on Tables 1-6 Suppl., significant differences 

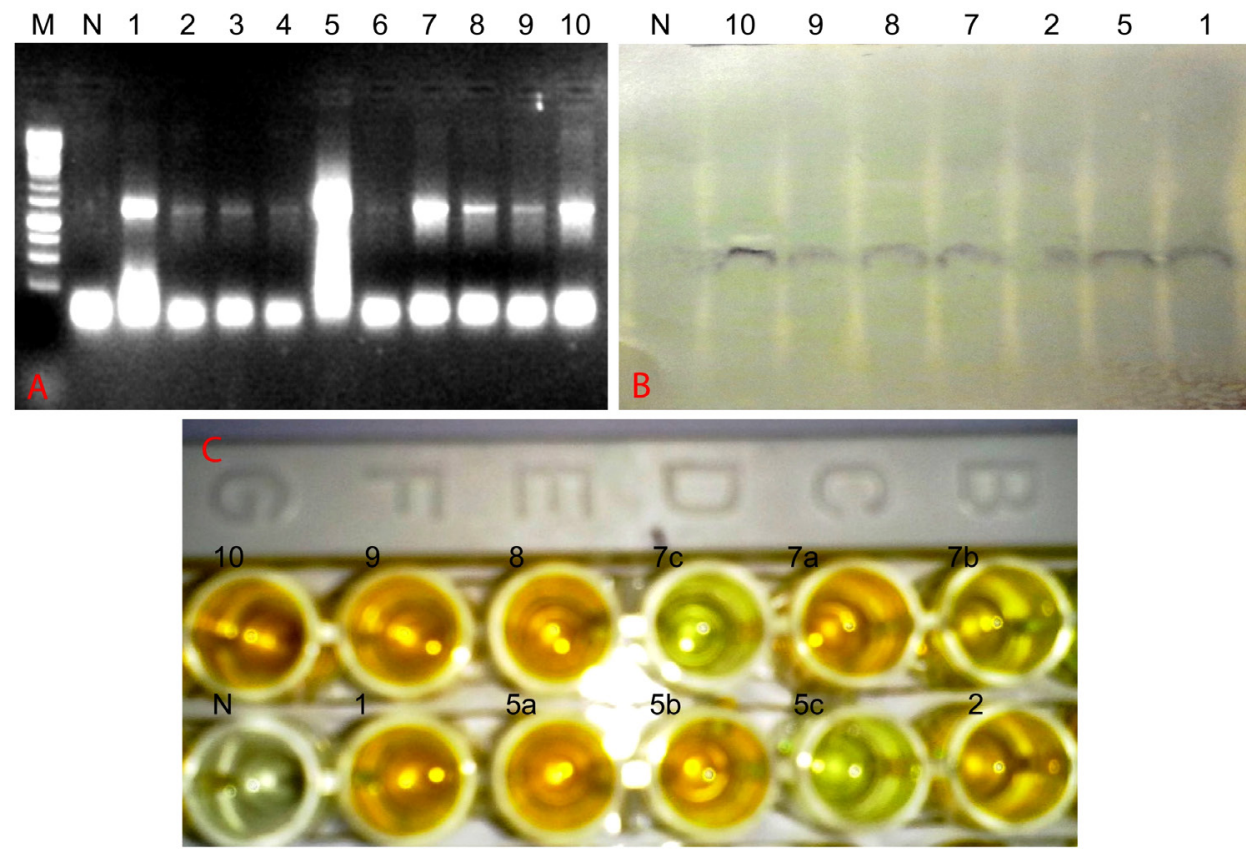

Fig. 5. $A$ - Molecular assay of transformed potato lines. M - 1-kb DNA ladder, N - wild-type plant, $1-10$ - independent transgenic lines. $B$ - DNA hybridization with biotin-labeled betaine aldehyde dehydrogenase $(B A D H)$ probes; genomic DNA was digested with BamH1 and $K p n 1$ restriction enzymes; $\mathrm{N}$ - wild-type plant, 1,5,2,7,8,9,10 - PCR-positive transgenic lines. $C$ - Enzyme-linked immunosorbent assay with $B A D H$ gene-specific antibodies, $\mathrm{N}$ - wild-type plant 1,5(a,b,c), 2,7(a,b,c),8,9,10 - independent transgenic lines.

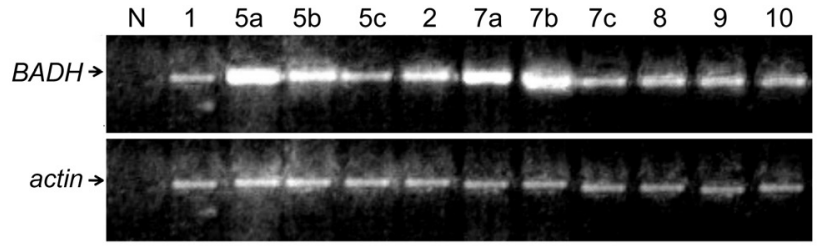

Fig. 6: Reverse transcription PCR analysis of betaine aldehyde dehydrogenase $(B A D H)$ expression in transgenic potato plants. $\mathrm{N}$ - wild-type plants, $1-10$ - transgenic plants; $5 \mathrm{a}$ and $7 \mathrm{a}$ contain the triple $C a M V 35 S$ promoter; $5 \mathrm{c}$ and $7 \mathrm{c}$ have a single $C a M V$ $35 S$ promoter; the others have the double $C a M V 35 S$ promoter.

were observed among salt stress treatments, transgenic plants, and interactions between stress treatments and transgenic plants for all studied traits. A strong and significant correlation was found between all studied traits except REC with MDA, $\mathrm{H}_{2} \mathrm{O}_{2}$, and proline. Experimental data show that due to the increased salt stress, the concentration of $\mathrm{H}_{2} \mathrm{O}_{2}$ increasesd, which casused a reduction in chlorophyll content. Activity of $B A D H$ increased proline, chlorophyll and MDA content while decreased $\mathrm{H}_{2} \mathrm{O}_{2}$ content (Table 8 Suppl.). The results show $B A D H$ activity positively influenced MDA, chlorophyll, and proline production (Table 9 Suppl). The regression equation was calculated as $\mathrm{Y}(B A D H$ activity $)=41.999$ +0.2402 (MDA) - $0.2979(\mathrm{REC})+5.0961$ (chlorophyll contents) $-0.00289\left(\mathrm{H}_{2} \mathrm{O}_{2}\right)+0.46527$ (proline)

\section{Discussion}

Salinity stress is a major problem for potato and other crops as it limits their yield (Boyer 2004). To provide salt tolerance and to identify quantitative trait loci with associated markers to enhance salt tolerance and to improve yield and quality, extensive rounds of breeding are needed (Foolad 1999). For maintaining optimum cellular metabolism and preventing cellular damage to cellular components, plants employ a number of protection mechanisms (Wood and Lenne 1997). The accumulation of osmoprotectants is the most common metabolic adaptation against salinity stress, and among these osmoprotectants proline and glycinebetaine are very important (Rhodes and Hanson 1993).

Potato does not possess a glycinebetaine metabolic synthesis pathway and so it is a weak or non-accumulator of glycinebetaine (Sakamoto and Murata 2000). Therefore, in engineered potatoes, the accumulation of stress-induced glycinebetaine can be essential (Rathinasabapathi 2000). It has been reported that the amount of $B A D H$ transcripts increases 2-fold in salt-stressed spinach and 3- and 4-fold in the taproots and leaves of sugar beet, respectively (Ma et al. 2012, Zhu et al. 2014). It has also been reported that $B A D H$ mRNA content increases up to 8-fold in barley leaves when exposed to salt, drought, and water stress, and the content decreased when the stresses are reduced (Saneoka et al. 2001). In salt-stressed plants, the accumulation of betaine is regulated by changes in betaine biosynthetic pathway genes, and the stress response of the $B A D H$ gene occurs via cis-regulatory elements (Ghosh et al. 2015).

In the current investigation, BADH was firstly subjected to an in silico analysis revealing this protein was structurally homologous to the queried protein (BADH) playing a vital role in salt tolerance of various plants. 
Both plant aminoaldehyde dehydrogenases-2 and plant aminoaldehyde dehydrogenases-1 have been reported to interact with sodium-isolated plant aminoaldehyde dehydrogenases-2, which is comparatively $83 \%$ identical to the $B A D H$ protein and contains 2 chains (A and $\mathrm{B}$ ), $2 \mathrm{Na}^{+}, 7$ glycerol molecules, 290 water molecules, and the ADP parts of two $\mathrm{NAD}^{+}$molecules (Tylichova et al. 2010). This protein is present mainly in the cytoplasm, as predicted by most of the protein localization prediction tools. It can interact with sodium ions and prevent the outflow of water from inside the cell. A phylogenetic tree was computed using 72 proteins with similar sequences from 11 monocot and 61 eudicot plants.

It was found that salt stress tolerant $B A D H$ gene could be amplified with gene specific primers and successfully cloned in adenine and thymine plant expression vectors (Fig. 2A) (Kiani et al. 2013). The BADH gene was introduced into potato plants with plant expression vector pCAMBIA 1301 under triple, double, and single CaMV $35 \mathrm{~S}$ promoters to enhance the constitutive expression (Jia et al. 2002, Kiani et al. 2013, Rao et al. 2013) (Fig 2B). Its integration into the potato genome was confirmed via DNA hybridization. $B A D H$-positive plants were subjected to DNA hybridization analysis with biotin-labeled genespecific probes, and the results were found to be remarkably consistent with the PCR results, as shown in Fig. 5A, $B$. No matter whether salt stress was present or not, transcripts of $B A D H$ gene were detectable, but when subjected to ELISA, the expression patterns were different under single, double, and triple CaMV $35 \mathrm{~S}$ promoters (Fig. 5C) (Rao et al. 2013, Muzaffar et al. 2015). This phenomenon could be due to the difference between the insertion points throughout the genome of each transformant (Guo et al. 1997, Liu et al. 2011, 2013, Van Leeuwen et al. 2014). Regarding the destructive effects of excess ROS on plant growth and development, they contributed to the adverse effects of environmental stresses. By using ascorbate as reducing power, it is known that a scavenger (superoxide dismutase) of superoxide radicals produce $\mathrm{H}_{2} \mathrm{O}_{2}$ and that is eliminated and broken down directly to form water and oxygen via BADH(Babakhani et al. 2013).

The functions of whole cells and plants depend on cell membranes. The physiological function of a cell is dependent on cell membrane permeability. Harsh conditions such as drought, salinity, and low and high temperatures initially damage the cell membrane and later affect its function; this phenomenon first causes leakage of the membrane and ultimately the loss of intracellular content. When nutritional solution without $\mathrm{NaCl}$ was used, small differences were observed in REC values between wild type and transgenic plants, but REC values increased when $\mathrm{NaCl}$ was applied. Despite the increase, the REC values of transgenic lines were significantly lower than those of the wild type plants (Fig. 4 Suppl.). These findings are consistent with those of Jia et al. (2002). Thus, the activation of glycinebetaine protects membranes of plant cells during salt stress (Hasegawa et al. 2000). APX activity increased and was maintained at a very high level in transgenic Arabidopsis plants by the overproduction of $\mathrm{BADH}$. During treatment with $\mathrm{NaCl}, B A D H$ expression in transgenic plants triggers the activation of oxygenscavenging system and protects plants from salt stress by equilibrating $\mathrm{H}_{2} \mathrm{O}_{2}$ metabolism (Tang et al. 2014 and Fig. 5 Suppl.) leading to increased chlorophyll content (Fig. 5 Suppl.).

Membrane protection against reactive oxygen speciesin plant cells is provided by proline, which acts as an electron acceptor (Rejeb et al. 2014). Unlike in wildtype plants, proline content was high in $B A D H$ transgenic plants (Fig. 6 Suppl.). Under stress conditions, MDA is the final product of lipid peroxidation (Puniran-Hartley et al. 2014). Before salt treatment, the MDA content was similar in both wild-type and transgenic plants, but after salt treatment, it was increased only in transgenic plants (Fig. 6 Suppl.). Glycine betaine content was dependent on promoter used and transgenic potato with the $B A D H$ gene inserted under triple promoter exhibited the highest glycine betaine content, which indicates that $B A D H$ expression was promoter dependent (Fig. 4). Even with a single promoter, glycine betaine content was higher compared with wild type plans but lower than with the double promoter. MDA, chlorophyll, and $\mathrm{H}_{2} \mathrm{O}_{2}$ content corresponded to glycinebetaine content.

Transgenic and wild-type plant shoots were put in MS medium supplemented with $90 \mathrm{mM} \mathrm{NaCl}$. All transgenic shoots rooted normally within 2 weeks, but in wild-type shoots, only stunted growth and callus-like formation were observed instead of rooting (Fig. 3). These findings are consistent with Jia et al. (2002) and Farace et al. (2015). The rooted potato shoots were transplanted to pots, after which they were watered with MS or MS with $90 \mathrm{mM}$ $\mathrm{NaCl}$.. During the vegetative stage, the transgenic plants grew well even under $120 \mathrm{mM} \mathrm{NaCl}$ solution, while the wild types either died or turned yellow (Fig. 6 Suppl.).

Most of the work relating to metabolic engineering has been focused on grasses and tobacco; hence, published reports on vegetables, such as tomato and potato, are scarce. For glycine betaine biosynthesis, $B A D H$ or other genes have been introduced from different plant species to increase salt stress tolerance (Rathinasabapathi 2000, Cookson et al. 2013). The results from our correlation and regression analyses showed that $B A D H$ activity plays an important role in the increased production of proline and chlorophyll (Ali et al. 2013, 2014). The reduction of $\mathrm{H}_{2} \mathrm{O}_{2}$ content was also carried out in transgenic potato plants. Hence, the correlation and regression analyses provide an opportunity for the selection of salt-resistant potato genotypes (Ali et al. 2016). This is perhaps the first report on introducing Atriplex BADH in Pakistan potato cultivars.

\section{Conclusions}

Transgenic potato plants that harbored the $B A D H$ gene under the triple CaMV $35 \mathrm{~S}$ promoter could tolerate higher salt stress than those harbored the $B A D H$ gene under the single and double CaMV $35 \mathrm{~S}$ promoter and wild type plants. The triple CaMV $35 \mathrm{~S}$ promoter boosted the expression of $B A D H$ in transgenic potato plants leading to 4 to 4.5 -fold higher glycine betaine content compared 
with the wild type and also higher chlorophyll and proline content under salt stress.

\section{References}

Ali, Q., Ali, A., Ahsan, M., Ali, S., Khan, N.H., Muhammad, S., Abbas, H.G., Nasir, I.A., Husnain, T.: Line $\times$ tester analysis for morpho-physiological traits of Zea mays L. seedlings. Adv. Life Sci. 1: 242-253, 2014.

Ali, Q., Ahsan, M., Ali, F., Aslam, M., Khan, N.H., Munzoor, M., Mustafa, H.S.B., Muhammad, S.: Heritability, heterosis and heterobeltiosis studies for morphological traits of maize (Zea mays L.) seedlings. - Adv.. Life Sci. 1: 52-63, 2013.

Ali, Q., Ahsan, M., Kanwal, N., Ali, F., Ali, A., Ahmed, W., Ishfaq, M., Saleem, M.: Screening for drought tolerance: comparison of maize hybrids under water deficit condition. Adv. Life Sci. 3: 51-58, 2016

Axel, C., Zannini, E., Coffey, A., Guo, J., Waters, D.M., Arendt, E.K.: Ecofriendly control of potato late blight causative agent and the potential role of lactic acid bacteria: a review. - Appl. Microbiol. Biotechnol. 96: 37-48, 2012.

Babakhani, B., Khavari-Nejad, R., Fahimi, H., Saadatmand, S.: Biochemical responses of alfalfa (Medicago sativa L.) cultivars subjected to $\mathrm{NaCl}$ salinity stress. - Afr. J Biotechnol. 10: 11433-11441, 2013.

Bates, L., Waldren, R., Teare, I.: Rapid determination of free proline for water-stress studies. - Plant Soil 39: 205-207, 1973.

Boyer, J.: Differential Scanning Calorimetry in the Analysis of Foods. - Marcel Dekker, New York, 2004.

Chou, K.C., Shen, H.B.: Euk-mPLoc: a fusion classifier for large-scale eukaryotic protein subcellular location prediction by incorporating multiple sites. - J. Proteome Res. 6: 17281734, 2007.

Cookson, S.J., Moreno, M.J.C., Hevin, C., Mendome, L.Z.N., Delrot, S., Trossat-Magnin, C., Ollat, N.: Graft union formation in grapevine induces transcriptional changes related to cell wall modification, wounding, hormone signalling, and secondary metabolism. - J. exp. Bot. 64:, 2013.

Diaz-Sanchez, Á.G., González-Segura, L., Mújica-Jiménez, C., Rudiño-Piñera, E., Montiel, C., Martínez-Castilla, L.P., Muñoz-Clares, R.A.: Amino acid residues critical for the specificity for betaine aldehyde of the plant ALDH10 isoenzyme involved in the synthesis of glycine betaine. - Plant Physiol. 158: 1570-1582, 2012.

Farace, G., Visconti, S., Marchive, C., Aducci, P., Marra, M., Trossat-Magnin, C.: Characterization, functional validation and gene expression patterns of two 14-3-3 isoforms from Vitis vinifera. - Vitis 54: 33-40, 2015.

Foolad, M.: Comparison of salt tolerance during seed germination and vegetative growth in tomato by QTL mapping. -Genome 42: 727-734, 1999

Fujiwara, T., Hori, K., Ozaki, K., Yokota, Y., Mitsuya, S., Ichiyanagi, T., Hattori, T. and Takabe, T.: Enzymatic characterization of peroxisomal and cytosolic betaine aldehyde dehydrogenases in barley. - Physiol. Plant. 134: 2230, 2008

Gasteiger, E., Gattiker, A., Hoogland, C., Ivanyi, I., Appel, R.D., Bairoch, A.: ExPASy: the proteomics server for in-depth protein knowledge and analysis. -Nucl. Acids Res. 31: 37843788, 2003.

Ghosh, P., Rathinasabapathi, B., Teplitski, M., Ma, L.Q.: Bacterial ability in $\mathrm{As}^{\mathrm{III}}$ oxidation and $\mathrm{As}^{\mathrm{V}}$ reduction: relation to arsenic tolerance, $\mathrm{P}$ uptake, and siderophore production. Chemosphere. 30: 995-1000, 2015.
Giri, J.: Glycinebetaine and abiotic stress tolerance in plants. Plant Signal. Behav. 6: 1746-1751, 2011.

Guo, Y., Zhang, L., Xiao, G., Cao, S., Gu, D., Tian, W., Chen, S.: Expression of betaine aldehyde dehydrogenase gene and salinity tolerance in rice transgenic plants. - Sci. China Series C: Life Sci. 40: 496-501, 1997.

Hasegawa, P.M., Bressan, R.A., Zhu, J.-K., Bohnert, H.J.: Plant cellular and molecular responses to high salinity. - Annu. Rev. Plant Biol. 51: 463-499, 2000.

Hemraj, V., Diksha, S. and Avneet, G.: A review on commonly used biochemical test for bacteria. Innovare J Life Sci, 1: 1-7, 2013.

Hou, Q., Bartels, D.: Comparative study of the aldehyde dehydrogenase (ALDH) gene superfamily in the glycophyte Arabidopsis thaliana and Eutrema halophytes. - Ann. Bot. 115: 465-479, 2014

Ishitani, M., Arakawa, K., Mizuno, K., Kishitani, S., Takabe, T.: Betaine aldehyde dehydrogenase in the Gramineae: levels in leaves of both betaine-accumulating and nonaccumulating cereal plants. - Plant Cell Physiol. 34: 493-495, 1993.

Jbir-Koubaa, R., Charfeddine, S., Ellouz, W., Saidi, M. N., Drira, N., Gargouri-Bouzid, R., Nouri-Ellouz, O.: Investigation of the response to salinity and to oxidative stress of interspecific potato somatic hybrids grown in a greenhouse. - Plant Cell Tissue Organ Cult. ??: 1-15, 2014

Jia, G.-X., Zhu, Z.-Q., Chang, F.-Q., Li, Y.-X.: Transformation of tomato with the $B A D H$ gene from Atriplex improves salt tolerance. - Plant Cell Rep. 21: 141-146, 2002.

Kiani, S., Ali, A., Bajwa, K. S., Muzaffar, A., Ashraf, M.A., Samiullah, T.R., Shahid, A., Husnain, T.: Cloning and chloroplast-targeted expression studies of insect-resistant gene with ricin fusion-gene under chloroplast transit peptide in cotton. - Electron. J. Biotechnol. 16: 1-14, 2013.

Krivosheeva, A., Varlamova, T., Yurieva, N., Sobol'kova, G., Kholodova, V., Belyaev, D.: Potato transformation with the $H v N H X 3$ gene and the improvement of transformant salt tolerance. - Russ. J. Plant Physiol. 61: 792-800, 2014.

Levy, D., Tai, G.: Differential response of potatoes (Solanum tuberosum L.) to salinity in an arid environment and field performance of the seed tubers grown with fresh water in the following season. - Agr. Water Manage. 116: 122-127, 2013.

Liu, X., Cheng, S., Liu, J., Ou, Y., Song, B., Zhang, C., Lin, Y., Li, X.-Q., Xie, C.: The potato protease inhibitor gene, plays roles in the cold-induced sweetening of potato tubers by modulating invertase activity. - Postharvest Biol. Technol. 86: 265-271, 2013.

Liu, X., Zhang, C., Ou, Y., Lin, Y., Song, B., Xie, C., Liu, J., Li, X.Q.: Systematic analysis of potato acid invertase genes reveals that a cold-responsive member, StvacINV1, regulates cold-induced sweetening of tubers. - Mol. Genet. Genomics 286: 109-118, 2011.

Luo, D., Niu, X., Yu, J., Yan, J., Gou, X., Lu, B.-R., Liu, Y.: Rice choline monooxygenase (OsCMO) protein functions in enhancing glycine betaine biosynthesis in transgenic tobacco but does not accumulate in rice (Oryza sativa L. ssp. japonica). - Plant Cell Rep. 31: 1625-1635, 2012.

Ma, L.Q., Rathinasabapathi, B., Wang, X., Mathews, S., Ghosh, P.: Arsenic biotransformation and transfer from rhizosphere to plant. - In: Ng, J.C., Noller, N., Naidu, R., Bundschuh, J., Bhattacharya, P. (ed.): Proceedings of the $4^{\text {th }}$ International Congress on Arsenic in the Environment. P. 101. CRC Press, Cairns, 2012.

Mitsuya, S., Kuwahara, J., Ozaki, K., Saeki, E., Fujiwara, T., Takabe, T.: Isolation and characterization of a novel peroxisomal choline monooxygenase in barley. - Planta 234: 1215-1226, 2011. 
Murashige, T., Skoog, F.: A revised medium for rapid growth and bio assays with tobacco tissue cultures. - Physiol. Plant. 15: 473-497, 1962.

Muzaffar, A., Kiani, S., Khan, M.A.U., Rao, A.Q., Ali, A., Awan, M.F., Iqbal, A., Nasir, I.A., Shahid, A.A., Husnain, T.: Chloroplast localization of Cry1 Ac and Cry2A protein - an alternative way of insect control in cotton. - Biol. Res. 48: $1-11,2015$.

Nakamura, T., Nomura, M., Mori, H., Jagendorf, A.T., Ueda, A., Takabe, T.: An isozyme of betaine aldehyde dehydrogenase in barley. - Plant Cell Physiol. 42: 1088-1092, 2015.

Pieper, U., Eswar, N., Davis, F. P., Braberg, H., Madhusudhan, M S., Rossi, A., Marti-Renom, M., Karchin, R., Webb, B.M., Eramian, D.: MODBASE: a database of annotated comparative protein structure models and associated resources. - Nucl. Acids Res. 34: D291-D295, 2006.

Puniran-Hartley, N., Hartley, J., Shabala, L., Shabala, S.: Salinity-induced accumulation of organic osmolytes in barley and wheat leaves correlates with increased oxidative stress tolerance: in planta evidence for cross-tolerance. - Plant Physiol. Biochem. 83: 32-39, 2014.

Rajaeian, S., Ehsanpour, A.A., Javadi, M., Shojaee, B.: Ethanolamine induced modification in glycine betaine and proline metabolism in Nicotiana rustica under salt stress. Biol. Plant. 61: 797-800, 2017.

Rao, A.Q., Bajwa, K.S., Puspito, A.N., Khan, M., Abbas, M.A., Bakhsh, A., Shahid, A.A., Nasir, I.A., Husnain, T.: Variation in expression of phytochrome B gene in cotton (Gossypium hirsutum L.). - J. agr. Sci. Technol. 15: 1033-1042, 2013.

Rathinasabapathi, B.: Metabolic engineering for stress tolerance: installing osmoprotectant synthesis pathways. - Ann. Bot. 86: 709-716, 2000.

Rathinasabapathi, B., Burnet, M., Russell, B.L., Gage, D.A., Liao, P.-C., Nye, G.J., Scott, P., Golbeck, J.H., Hanson, A.D.: Choline monooxygenase, an unusual iron-sulfur enzyme catalyzing the first step of glycine betaine synthesis in plants: prosthetic group characterization and cDNA cloning. - Proc. nat. Acad. Sci. USA 94: 3454-3458, 1997.

Rhodes, D., Hanson, A.: Quaternary ammonium and tertiary sulfonium compounds in higher plants. - Annu. Rev. Plant Biol. 44: 357-384, 1993.

Sakamoto, A., Murata, N.: Genetic engineering of glycinebetaine synthesis in plants: current status and implications for enhancement of stress tolerance. - J. exp. Bot. 51: 81-88, 2000.

Saneoka, H., Ishiguro, S., Moghaieb, R.E.: Effect of salinity and abscisic acid on accumulation of glycinebetaine and betaine aldehyde dehydrogenase mRNA in Sorghum leaves (Sorghum bicolor). - J. Plant Physiol. 158: 853-859, 2001.

Si, H., Zhang, N., Wang, D.: Drought and salinity tolerance in transgenic potato. - In: He Z., Larkin R., Honeycutt W. (ed.): Sustainable Potato Production: Global Case Studies. Pp. 373387. Springer, Dordrecht 2012.
Sudhersan, C., Manuel, S.J., Ashkanani, J., Al-Ajeel, A.: In vitro screening of potato cultivars for salinity tolerance. -Amer. Eurasian J. Sustain. Agr. 6: 344-348, 2012.

Tang, W., Sun, J., Liu, J., Liu, F., Yan, J., Gou, X., Lu, B.R., Liu, Y.: RNAi-directed downregulation of betaine aldehyde dehydrogenase 1 (OsBADH1) results in decreased stress tolerance and increased oxidative markers without affecting glycine betaine biosynthesis in rice (Oryza sativa). - Plant mol. Biol. 86: 443-454, 2014.

Tylichová, M., Kopečný, D., Moréra, S., Briozzo, P., Lenobel, R., Snégaroff, J., Śebela, M.: Structural and functional characterization of plant aminoaldehyde dehydrogenase from Pisum sativum with a broad specificity for natural and synthetic aminoaldehydes. - J. mol. Biol. 396: 870-882, 2010.

Van Leeuwen, J., Lehtinen, T., Lair, G., Bloem, J., Hemerik, L., Ragnarsdóttir, K., Gísladóttir, G., Newton, J., De Ruiter, P.: An ecosystem approach to assess soil quality in organically and conventionally managed farms in Iceland and Austria, 2014. Soil Discuss. 1: 201-237, 2014.

Weretilnyk, E.A., Hanson, A.D.: Betaine aldehyde dehydrogenase from spinach leaves: purification, in vitro translation of the mRNA, and regulation by salinity. - Arch. Biochem. Biophys. 271: 56-63, 1989.

Wood, D., Lenne, J.M.: The conservation of agrobiodiversity on-farm: questioning the emerging paradigm. - Biodiversity Conserv. 6: 109-129, 1997.

Wood, E.M., Miles, T.D., Wharton, P.S.: The use of natural plant volatile compounds for the control of the potato postharvest diseases, black dot, silver scurf and soft rot. - Biol. Control 64: 152-159, 2013.

Xiao, G., Zheng, F., Qiu, Z., Yao, Y.: Impact of climate change on water use efficiency by wheat, potato and corn in semiarid areas of China. - Agr. Ecosyst. Environ. 181: 108-114, 2013.

Xing, W., Rajashekar, C.: Glycine betaine involvement in freezing tolerance and water stress in Arabidopsis thaliana. Environ. exp. Bot. 46: 21-28, 2001.

Yu, C.S., Chen, Y.C., Lu, C.H., Hwang, J.K.: Prediction of protein subcellular localization. - Proteins: Struct. Funct. Bioinform. 64: 643-651, 2006.

Yu, H.Q., Zhou, X.Y., Wang, Y.G., Zhou, S.F., Fu, F.L., Li, W.C.: A betaine aldehyde dehydrogenase gene from Ammopiptanthus nanus enhances tolerance of Arabidopsis to high salt and drought stresses. - Plant Growth Regul. 83: 265-276, 2017.

Zhang, H., Lu, L., Chen, L., Tao, Z., Chen, F., Zhong, S., Liu, Y., Tian, Y., Yan, P.: Molecular cloning, expression, and regulation of the ovalbumin gene in pigeon oviduct epithelial cells. - Genet. mol. Res. 13: 117-126, 2014.

Zhang, J.-L., Shi, H.: Physiological and molecular mechanisms of plant salt tolerance. - Photosynth. Res. 115: 1-22, 2013.

Zhu, L.J., Guan, D.X., Luo, J., Rathinasabapathi, B., Ma, L.Q.: Characterization of arsenic-resistant endophytic bacteria from hyperaccumulators Pteris vittata and Pteris multifida. Chemosphere 113: 9-16, 2014. 